\title{
Note on the Ubiquitous Cercaria from Littorina rudis, L. obtusata and L. littorea.
}

By

W. J. Rees, M.Sc.,

Marine Biological Laboratory, Plymouth.

With 1 Text-Figure.

THIS cercaria was found to be very common in specimens of Littorina rudis (Maton) and $L$. obtusata (Linné) collected at Aberystwyth during February and March, 1935, occurring in twenty out of fifty specimens of $L$. rudis and in four out of forty specimens of $L$. obtusata. It was, on the other hand, very rare in $L$. littorea, only two infested individuals being found out of a total of two thousand molluscs examined. In all three species of mollusc the parts of the digestive gland most heavily infested appeared white or creamy-white in colour.

The form described here appears to be almost identical with Cercaria ubiquitoides recorded by Stunkard (1932) from $L$. littorea and $L$. rudis occurring on the coast of Brittany. Certain differences are found between my specimens and those of Stunkard. It is difficult to determine whether these differences are individual or specific because there are so few larval characters in cercariæ of the Ubiquita group which can be used for separating species. The problem is rendered more difficult by the close resemblance of the adult trematodes (species of the genus Spelotrema).

\section{Parthentta.}

The sporocysts are small oval or rounded and colourless, and may contain from six to thirty cercariæ in various stages of development. The sporocysts vary in length from $0.25-0.75 \mathrm{~mm}$., with an average length of $0.6 \mathrm{~mm}$., so reaching a much greater length measurement than that recorded by Stunkard for $C$. ubiquitoides, which was from 0.25-0.45 mm.

\section{Cercaria.}

Below is given a comparison of measurements of the present specimens with those of Stunkard, based on the measurements of 
twenty-five normally emerged cercariæ. All the figures except that for the body length expanded are average values, and are expressed in $\mathrm{mm}$.

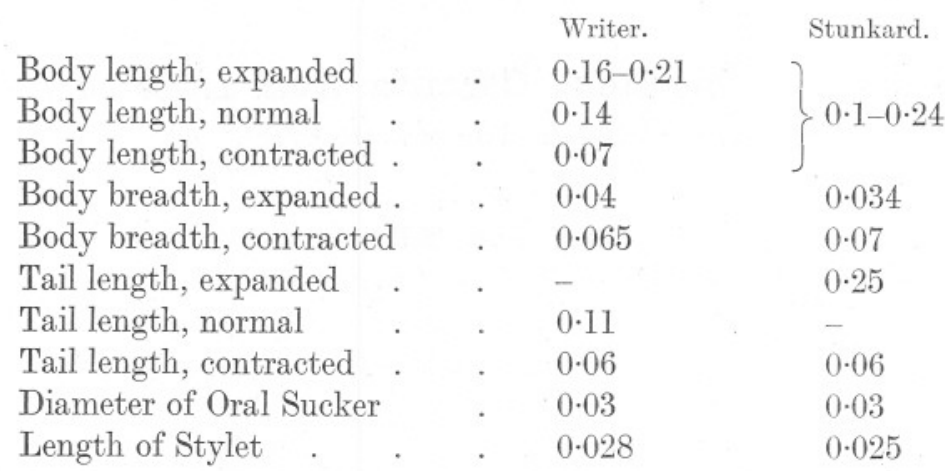

The present form was never observed to reach a length of $0 \cdot 24$ and the stylet also seems a little longer than in $C$. ubiquitoides.

Stunkard observes that the penetration gland cells do not stain with neutral red. In the present specimens the penetration gland cells do not readily take up neutral red as an intravital stain. The gland cells consist of four pairs of cells each with its own duct which arises dorsally in each case. Each cell of the anterior pair sends a median duct forwards and these ducts cross the face of the sucker to open on either side of the stylet. The ducts of the remaining three pairs of cells are grouped in a common bundle and also open separately on either side of the stylet. The penetration gland cells are not lobed in the present form and the most anterior pair is situated a little way in front of the other cells. Of these four pairs of cells only the two anterior pairs and their ducts take up the intravital stain, staining a deep red. The remaining cells and their ducts have never been observed to take up the intravital stain. The arrangement of these cells which differs a little from those of Stunkard is shown in Figure 1.

The body also contains cystogenous cells scattered over its whole surface. Their cell outlines are very diffuse and they have not been figured.

The excretory vesicle is reniform, the main collecting tubules arise from it antero-laterally and pass forwards laterally to the level of the penetration gland cells where each divides into anterior and posterior collecting tubules. Two flame cells were observed, one lateral to the group of penetration gland cells and the other also lateral midway between the latter and the anterior border of the excretory vesicle.

In the region between the excretory bladder and the penetration gland cells there is a compact median mass of cells which is very difficult to see even in intravitally stained specimens. There is a very small papilla 


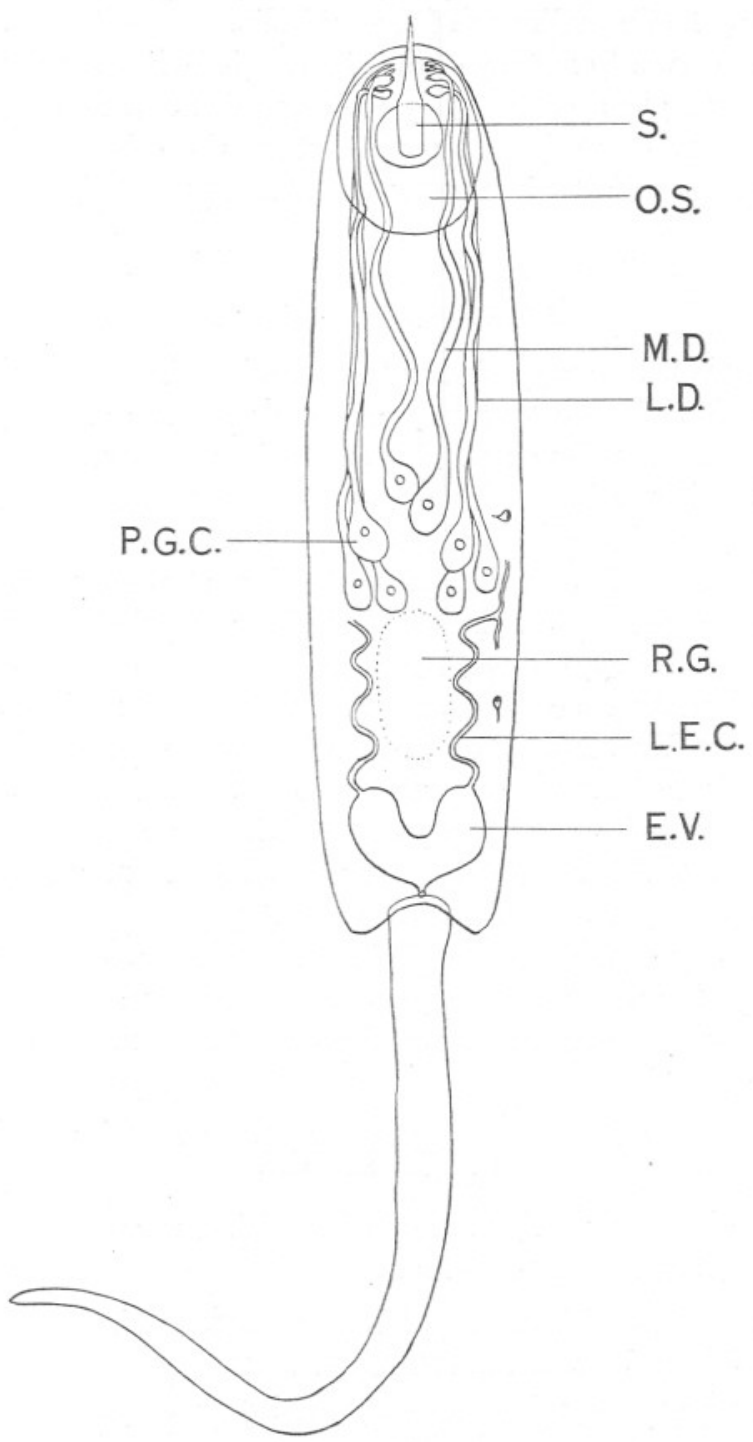

Fig. 1.-General Anatomy of the Cerearia. (The figure has been drawn with the aid of a camera lucida and is semi-diagrammatic.)

e.v., excretory vesicle; l.e.c., lateral excretory duct; l.d., lateral group of ducts; m.d., median duct; o.s., oral sucker; p.g.c., penetration gland cell ; r.g., rudiment of genital organs ; s., stylet. 
situated over this mass. It may be the anlage of the genital sucker and the mass may be the rudiment of the genitalia.

This form differs from that of Stunkard chiefly in the arrangement of the penetration gland cells. They are more distinct, not lobed and the most anterior pair of cells is separated from the other three pairs. In addition there are slight differences in measurements.

\section{Note on Life History.}

This cercaria is also very similar to Cercaria ubiquita Lebour, differing chiefly from it in having four pairs of penetration gland cells instead of six pairs. Lebour believed C. ubiquita to be the larval form of Spelotrema excellens Nicoll, but did not experimentally prove this to be so. The encysted stage probably occurs in a shore crustacean.

The only marine birds which are commonly seen near the rocks from which the present snails have been collected are the gulls, more particularly the herring gull, Larus a. argentatus Pont. The only Spelotrema sp. which Lewis (1926) records from the herring gull in his survey of the "Helminths of Wild Birds" of the area is Spelotrema simile Jagerskiöld, who found it to be very common in this bird. The writer has also found Spelotrema simile to be very common in all species of gulls (except L. marinus L., which has not been examined for helminths). Only one specimen of Spelotrema excellens was found.

The unusually high percentage infestation of Littorina rudis with this cercaria, together with the high percentage of gulls parasitised by Spelotrema simile, suggests that this may be the larval form of this species.

\section{REFERENCES.}

Lebour, M. V. 1911. A Review of British Marine Cercariæ. Parasitology, Vol. IV, pp. 416-456.

Lewis, E. A. 1926. Helminths of Wild Birds found in the Aberystwyth Area. Journ. Helminth., Vol. 4, pp. 7-12.

Stunkard, H. W. 1932. Some larval trematodes from the coast in the region of Roscoff, Finistère. Parasitology, Vol. 24, pp. 321-343. 